\title{
АКТУАЛЬНЫЕ ОСОБЕННОСТИ ОСУЩЕСТВЛЕНИЯ ГОСУДАРСТВЕННОЙ РЕГИСТРАЦИИ ПРАВ НА НЕДВИЖИМОЕ ИМУЩЕСТВО
}

\section{Полина Евгеньевна Иваненко}

Сибирский государственный университет геосистем и технологий, 630108, Россия, г. Новосибирск, ул. Плахотного, 10, обучающийся, тел. (923)231-46-54, e-mail: polli-holli@mail.ru

\section{Елена Сергеевна Стегниенко}

Сибирский государственный университет геосистем и технологий, 630108, Россия, г. Новосибирск, ул. Плахотного, 10, старший преподаватель кафедры кадастра и территориального планирования, тел. (383)361-05-66, e-mail: es.st@inbox.ru

В статье рассмотрена процедура подачи документов для государственной регистрации прав на недвижимое имущество в электронном виде, изучена статистика заявлений, поданных с помощью электронных ресурсов, в условиях пандемии. Разработана процессуальная схема осуществления государственной регистрации прав при подаче документов в электронном виде, выявлены недостатки существующей системы.

Ключевые слова: государственная регистрация прав, недвижимое имущество, единый государственный реестр недвижимости, орган регистрации прав, усиленная квалифицированная электронная подпись, электронный документ, электронный образ документа

\section{CURRENT FEATURES OF STATE REGISTRATION OF RIGHTS TO REAL ESTATE PROPERTY}

\section{Polina E. Ivanenko}

Siberian State University of Geosystems and Technologies, 10, Plakhotnogo St., Novosibirsk, 630108, Russia, Student, phone: (923)231-46-54, e-mail: polli-holli@mail.ru

\section{Elena S. Stegnienko}

Siberian State University of Geosystems and Technologies, 10, Plakhotnogo St., Novosibirsk, 630108, Russia, Senior Lecturer, Department of Cadastre and Territorial Planning, phone: (383)361-05-66, e-mail: es.st@inbox.ru

The article discusses the procedure for filing documents for state registration of rights to real estate in electronic form, statistics of applications filed using electronic resources in a pandemic is studied. A procedural scheme was developed for the implementation of state registration of rights when submitting documents in electronic form, the shortcomings of the existing system was identified.

Keywords: state registration of rights, real estate, unified state register of real estate, registration authority, enhanced qualified electronic signature, electronic document, electronic image of a document

Недвижимость представляет собой один из самых ценных объектов гражданских правоотношений. Права на недвижимое имущество и сделки с ним затрагивают интересы каждого гражданина и юридического лица. Для государства важно 
наличие достоверной информации об объектах недвижимости, это обусловлено тем, что недвижимое имущество в Российской Федерации, как и в большинстве стран мира, облагается налогами, доходы от которых наполняют бюджеты. В связи с этим российским законодательством предусматривается обязательная регистрация прав на недвижимость.

Государственная регистрация прав есть акт признания органами власти возникновения, изменения, перехода или прекращения прав на какой-либо объект недвижимости, а также ограничения прав и обременения объектов. Так эту процедуру определяет Федеральный закон «О государственной регистрации недвижимости» [1]. Там же установлено, что государственная регистрация прав единственное доказательство существующих прав на объект недвижимости, зарегистрированное право может быть оспорено только в судебном порядке. Таким образом, описываемая процедура призвана лишь удостоверить со стороны государства юридическую силу соответствующих правоустанавливающих документов. Тем самым государственная регистрация создает гарантии надлежащего выполнения сторонами обязательств и, следовательно, способствует упрочению и стабильности гражданского оборота в целом.

Правовую основу государственной регистрации прав составляют Конституция РФ, Гражданский кодекс РФ, Федеральный закон «О государственной регистрации недвижимости». Так, статьи 35 и 36 Конституции РФ гарантируют право на частную собственность, право на свободное владение, пользование и распоряжение каждому гражданину и защиту этих прав со стороны государства [2]. А статья 8.1 Гражданского Кодекса сообщает о необходимости обязательной государственной регистрации некоторых видов прав на имущество, к которым относятся и права на недвижимость [3].

Таким образом, регистрация прав на недвижимость необходима не только государству, но и собственникам - для получения гарантий своих имущественных прав.

Государственная регистрация прав осуществляется посредством внесения в Единый государственный реестр недвижимости записи о праве на недвижимое имущество, сведения о котором учтены в реестре объектов недвижимости.

Участниками отношений, возникающих при осуществлении государственного кадастрового учета и (или) государственной регистрации прав, являются обладатели прав на недвижимость, другие лица в предусмотренных законодательством случаях, в том числе граждане РФ, иностранные граждане и лица без гражданства, российские и иностранные юридические лица, международные организации, Союзное государство, иностранные государства, Российская Федерация, субъекты РФ, муниципальные образования, органы государственной власти РФ, органы государственной власти субъектов РФ и органы местного самоуправления, кадастровые инженеры, нотариусы, судебные приставы-исполнители, с одной стороны, и орган регистрации прав - с другой. Органом регистрации прав является Федеральная служба государственной регистрации, кадастра и картографии - Росреестр $[4,5]$. 
Органом регистрации прав предоставляется возможность подать документы для регистрации прав различными способами [1]:

- посредством личного обращения в отделение Росреестра либо многофункциональный центр (МФЦ);

- почтовым отправлением;

- в электронном виде.

Последний способ является наиболее востребованным в настоящее время, так как позволяет обратиться с заявлением о регистрации прав, не посещая лично никаких учреждений, что важно в условиях пандемии коронавирусной инфекции.

Так, согласно статистическим данным Росреестра треть заявлений на регистрацию прав собственности на недвижимость подаются в электронном виде. При этом доля электронных заявлений за три квартала 2020 года возросла на 54\% по сравнению с аналогичным периодом прошлого года.

Всего за указанный период в электронном виде поступило 4,6 млн заявлений на регистрацию прав собственности, что на 34 \% больше, чем с января по сентябрь 2019 года. На осуществление кадастрового учета поступило 615,8 тыс. обращений в электронном виде, что больше на 3,5 \% [6, 7]. При этом общее количество заявлений на регистрацию прав собственности за указанный период снизилось на $10 \%$, составив 15,2 млн, что связано с ограничениями в работе МФЦ в период пандемии коронавируса.

Существенный рост востребованности у участников рынка недвижимости электронных сервисов Росреестра был зафиксирован в 1-3 квартале 2020 года. Доля электронных запросов сведений ЕГРН за указанный период составила 91 \%. Общее количество сведений ЕГРН, предоставленных Росреестром за указанный период, увеличилось на 4 \% и составило 68,4 млн. При этом самыми популярными электронными сервисами Росреестра стали «Запрос посредством доступа к ФГИС ЕГРН», «Справочная информация по объектам недвижимости в режиме Online» и «Выписка из ЕГРН об основных характеристиках и зарегистрированных правах на объект недвижимости» $[6,7]$.

Далее, после частичного снятия ограничений, введенных во время пандемии, Росреестр заявил о восстановлении в России динамики учетно-регистрационных действий и возвращении на уровень средних показателей 2019 года. При этом электронными сервисами ведомства россияне пользуются активнее, чем в прошлом году (рис. 1).

Однако у электронной подачи документов существуют свои особенности.

Например, согласно пункту 1.1 статьи 16 Закона о регистрации заявление и иные необходимые документы должны быть поданы в форме электронных документов, электронных образов документов, заверенных усиленной квалифицированной электронной подписью (далее - УКЭП) заявителя [1]. Порядок представления заявления и иной требуемой документации в электронной форме утвержден приказом Минэкономразвития России от 29.11.2013 № 723 [8], согласно которому заявителям необходимо приобрести УКЭП, что может быть затруднительно и затратно. 


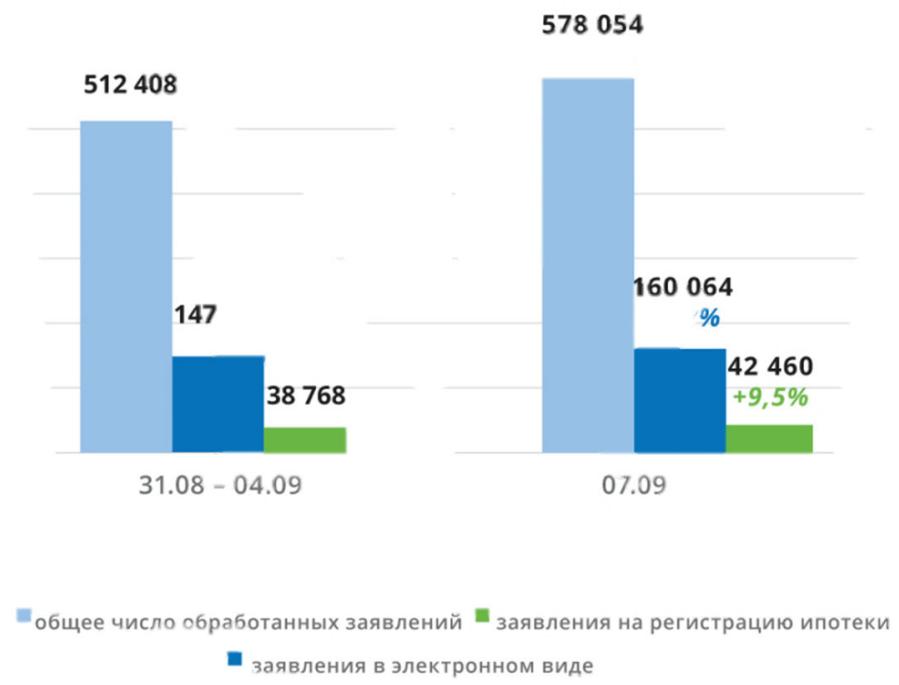

Рис. 1. Динамика учетно-регистрационных действий Росреестра на начало сентября 2020 года

Электронная подпись является аналогом собственноручной подписи и используется для определения (идентификации) лица, подписывающего какойлибо акт. Она оформляется путем выдачи сертификата специальными удостоверяющими центрами, список которых приведен на сайте Росреестра. Использовать сертификат можно после установки специальной компьютерной программы «КриптоПро».

Заявление в форме электронного документа представляется путем заполнения формы такого заявления, размещенной на сайте Росреестра, и подписывается УКЭП заявителей. К самим документам, направляемым способом электронной подачи, также существуют определенные требования. Электронные документы подаются в виде файлов в формате XML-документов и в виде электронных образов документов в формате PDF. Отсканированные или сфотографированные документы преобразуются в формат PDF в масштабе 1:1 к бумажному оригиналу. При этом их качество должно быть таким, чтобы сохранялась возможность прочитать текст документа полностью и определить его реквизиты. Если информация размещена на двух и более листах, в электронном виде она должна быть представлена в виде одного файла. При создании электронных копий документов используется монохромный режим с разрешением 300 dpi [8]. К заявлению может быть приложен перечень документов, где указываются наименование, дата, номер документа, а также название и размер соответствующих им файлов.

Из особенностей также стоит отметить тот факт, что размер государственной пошлины снижается на 30 \% при подаче документов на проведение госрегистрации в электронном виде, что определено пунктом 4 статьи 333.35 Налогового кодекса РФ [9]. Размер государственной пошлины за совершение юридически значимых действий в отношении физических лиц, применяется с учетом 
коэффициента 0,7 в случае совершения указанных действий с использованием единого портала государственных и муниципальных услуг и получением результата услуги в электронной форме.

Еще один нюанс заключается в сокращении срока проведения государственной регистрации. Государственная регистрация прав на основании нотариально удостоверенных документов, представленных в электронной форме, и поданного в электронной форме заявления о государственной регистрации прав проводится не позднее чем в течение одного рабочего дня, следующего за днем приема документов и указанного заявления [10].

Итогом анализа процедуры подачи документов для государственной регистрации прав на недвижимое имущество является следующая схема (рис. 2):

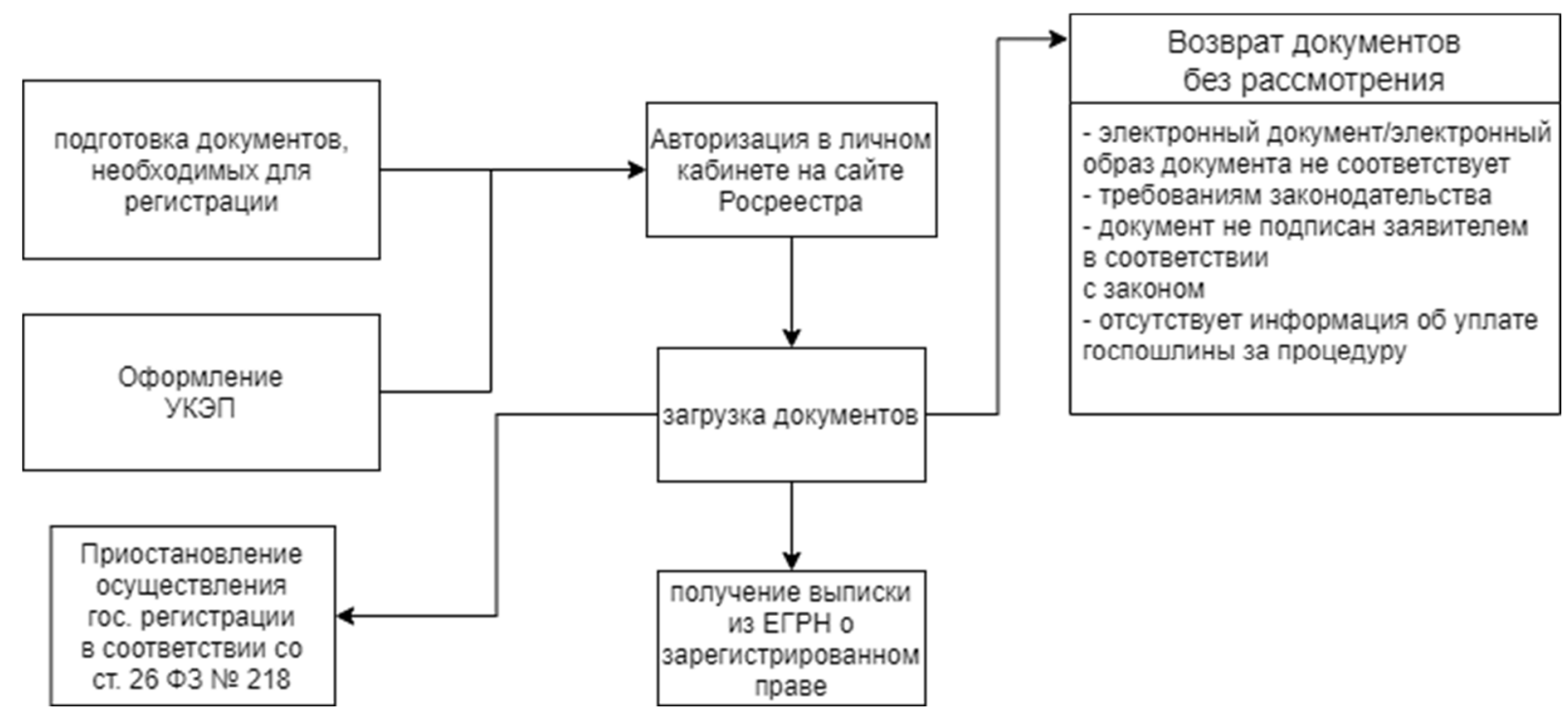

Рис. 2. Процессуальная блок-схема осуществления государственной регистрации прав при электронной подаче документов

Подводя итог, следует отметить, что процедура регистрации прав на недвижимое имущество методом электронной подачи документов, достаточно удобна, однако имеет свои недостатки. Главными среди них являются необходимость оформления усиленной квалифицированной электронной подписи и установка специального программного обеспечения. Также стоит отметить, что не каждый заявитель является уверенным пользователем ПК. Соответственно, у некоторых могут возникнуть сложности с подачей заявления самостоятельно.

Однако, несмотря на существующие сложности, способ подачи документов в электронном виде становится все более популярным, особенно в период пандемии. В связи с этим, Росреестр продолжает наращивать цифровую инфраструктуру в интересах заявителей. Ведомство разработало концепцию цифровой трансформации на 2021-2023 годы, на базе которой будет создан ряд клиентских сервисов для быстрого оформления недвижимости, удобного поиска земли для 
жилья и бизнеса и взаимодействия с кадастровыми инженерами [9]. Такой вектор развития учетно-регистрационной системы в Российской Федерации авторам представляется верным и соответствующим актуальному состоянию административно-правовой действительности.

\section{БИБЛИОГРАФИЧЕСКИЙ СПИСОК}

1. О государственной регистрации недвижимости [Электронный ресурс]: федер. закон от 13.07.2015 № 218-Ф3. - Доступ из справ.-правовой системы «КонсультантПлюс».

2. Конституция Российской Федерации [Электронный ресурс]: принята всенародным голосованием 12.12.1993 с изменениями, одобренными в ходе общероссийского голосования 01.07.2020. - Доступ из справ.-правовой системы «КонсультантПлюс».

3. Гражданский кодекс Российской Федерации (часть первая) [Электронный ресурс]: федер. закон от 30.11.1994 №51-Ф3. - Доступ из справ.-правовой системы «КонсультантПлюс».

4. Варламов, А. А., Кадастровая деятельность [Текст] : учебник / А. А. Варламов, С. А. Гальченко, Е. И. Аврунев; под общ. ред. А. А. Варламова. - 2-е изд., доп. - М. : ФОРУМ : ИНФРА-М, 2017. $-280 \mathrm{c}$.

5. Участники отношений, возникающих при государственной регистрации прав на недвижимое имущество и сделок с ним [Электронный ресурс]. - Режим доступа: https://lawbook.online/pravo-sobstvennosti-rossii/uchastniki-otnosheniy-voznikayuschih-pri32688.html - Загл. с экрана.

6. Каждое третье заявление на учетно-регистрационные действия поступает в росреестр в электронном виде [Электронный ресурс]. - Режим доступа: https://rosreestr.gov.ru/site/press/news/kazhdoe-trete-zayavlenie-na-uchetno-registratsionnyedeystviya-postupaet-v-rosreestr-v-elektronnom-v/ - Загл. с экрана.

7. Росреестр: доля электронных пакетов на регистрацию прав по итогам трех кварталов 2020 года увеличилась на 50\% [Электронный ресурс]. - Режим доступа: https://rosreestr.gov.ru/site/press/news/rosreestr-dolya-elektronnykh-paketov-na-registratsiyu-pravpo-itogam-tryekh-kvartalov-2020-goda-uvel/ - Загл. с экрана.

8. Приказ Минэкономразвития России от 22.11.2016 №738 «О внесении изменений в некоторые приказы Минэкономразвития России по вопросам предоставления сведений, содержащихся в Едином государственном реестре недвижимости».

9. Налоговый кодекс Российской Федерации (часть вторая) от 05.08.2000 №117-Ф3 (ред. от 23.11.2020).

10. Как подать в Росреестр электронные документы - пошаговая инструкция [Электронный ресурс]. - Режим доступа: http:/gorod-zarechny.ru/news/media/2020/7/9/kak-podat-vrosreestr-elektronnyie-dokumentyi-poshagovaya-instruktsiya/ - Загл. с экрана.

11. Липски, С. А. Правовое обеспечение землеустройства и кадастров: учеб. [Текст] / С. А. Липски. - М. : КноРус, 2016. - 432 с.

12. О кадастровой деятельности [Электронный ресурс]: федер. закон от 24.07.2007 № 221-Ф3. - Доступ из справ.-правовой системы «КонсультантПлюс».

(C) П. Е. Иваненко, Е. С. Стегниенко, 2021 